
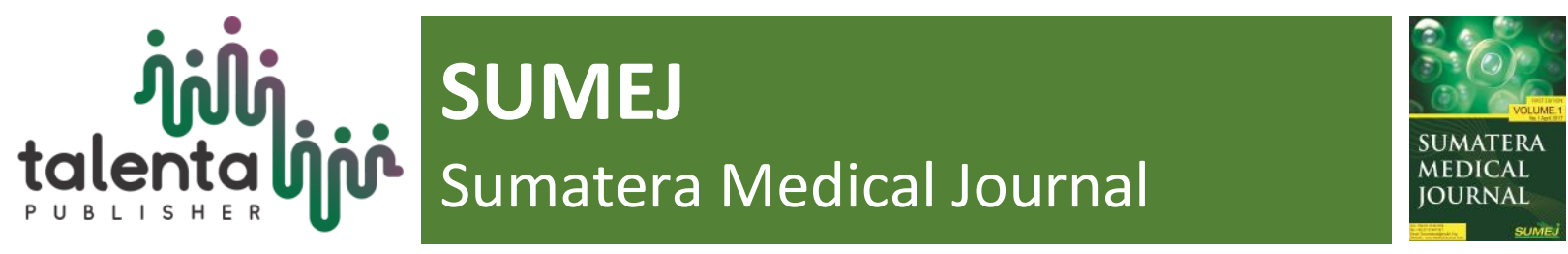

\title{
Dermatophyte Profile in Patients with Dermatophytosis in Polyclinic Dermatology and Venerology of the General Hospital Dr. Ferdinand Lumbantobing Sibolga in 2019
}

\author{
May Iyasya Sarumpaet ${ }^{1}$, Dian Dwi Wahyuni, \\ ${ }^{1}$ Faculty of Medicine, Universitas Sumatera Utara, Medan, Indonesia \\ ${ }^{2}$ Department of Microbiology Clinic, Universitas Sumatera Utara, Medan, Indonesia
}

\begin{abstract}
Dermatophytosis is a superficial skin infection caused by dermatophytes that infected keratinous skin tissue, dermatophytes form molecules that bind to keratin as a source of nutrients in the formation of colonization. Dermatophytes that cause dermatophytosis are Tricophyton sp, Epidermophyton $s p$ and Microsporum sp. To find out the Profile of dermatophytes in patients with dermatophytosis in the Polyclinic of Dermatology and Venerology Dr. Ferdinand Lumbantobing Sibolga in 2019 conducted observational research with cross sectional design. The sample of this study were 75 patients who were new patients and had not used antifungal drugs. This sample is then examined by examination of $\mathrm{KOH}$ and cultured and then identified by Scotch-tape Preparation in a microscope. The prevalence of dermatophytosis in this study was $23 \%$ of skin cases. The majority of dermatophytosis patients are women (52\%), the most age group is $46-65$ years (30.7\%) and is most often found in housewives (24\%). The dermatophytes species found were Trichophyton rubrum, Trichophyton mentagrophytes and Microsporum canis with the most species Trichophyton rubrum (37.3\%), which was then followed by Trichophyton mentagrophytes (16\%). Tinea corporis, tinea cruris, tinea capitis, tinea pedis and tinea unguinum are dermatophytosis cases that were found in this study. It can be concluded that Trichophyton rubrum is the most common cause of dermatophytosis in Dr. Ferdinand Lumbantobing Sibolga with Tinea corporis is the most classified classification of dermatophytosis.
\end{abstract}

Keyword: Dermatophytosis, Tinea Corporis, Tricophyton rubrum

Received date month year. | Revised date month year | Accepted date month year

\section{Introduction}

Dermatophytosis is a superficial skin infection caused by fungal dermatophytes that attack keratin-containing skin tissues such as the stratum corneum, hair and nails [1]. Dermatophytes are a group of fungi that have the ability to form molecules that bind to keratin and use them as a source of nutrients for colonization [2]. The causes of dermatophytosis are species from

${ }^{*}$ Corresponding author at: Faculty of Medicine, Universitas Sumatera Utara, Medan, Indonesia

E-mail address: may.iyasya@gmail.com 
Microsporum, Trichophyton, and Epidermophyton, which are grouped in the Deuteromycetes class [3]. Dermatophytosis is also commonly referred to as tinea and is named according to its anatomical location such as tinea capitis, tinea barbae, tinea corporis, tinea cruris, tinea unguium, tinea manus and tinea pedis [4].

Dermatophytosis is spread throughout the world with a different prevalence in each country [5]. This fungal infection is found in developing countries and countries with tropical climates and has high temperatures and humidity [6]. In addition, this disease affects many people who do not understand cleanliness and work in hot places and sweat a lot [7].

A cross sectional study conducted in Kazakhstan in 2017 with 195 cases of dermatophytosis in hospitals in the Almaty area from January to December 2014 showed dermatophytosis is still one of the problems in skin infections. Most cases occur in men (68.2\%) with the highest incidence occurring in the 1-9 years age group (41.5\%) of the total patients identified [8]. In Ethiopia, in a case study conducted in May 2017 to April 2018 at the Arsho Health Laboratory in Addis Ababa involving 318 patients diagnosed with dermatophytosis, the most common clinical manifestation was tinea capitis with a percentage of $48.1 \%$ and occurred mostly in the age group 1-14 years [9].

Until now, the incidence of dermatophytosis in Indonesia has been reported to be still quite high. In West Java Bramono et al reported that dermatophytosis was widely distributed in rural areas with the main cause of Trichophyton rubrum, whereas in Samarinda, East Kalimantan (20092010), it was found that dermatomycosis occupies the 2 nd place in the top 10 skin and venereal diseases, and dermatophytosis is the second most infections. The most common clinical type of dermatophytosis is tinea cruris $(41.46 \%)$, generally in men $(54.88 \%)$ with the main cause of Trichophyton rubrum [10]. It was reported in a study conducted by janitors in Tasikmalaya, found that of 20 people, 8 people were diagnosed with tinea pedis with $15 \%$ of them caused by Trichophyton rubrum [11]. In addition, according to research conducted at Prof. RSUP Dr. RD Kandou Manado found out of a total of 4,099 cases of skin disease in 2013, there were 153 (3.7\%) dermatophytosis cases with the highest percentage being tinea cruris (35.3\%) with an age group of 45-64 years (32.7\%) and female sex (60.8\%) [12]. In 2017, a study conducted by Yosie Anra et al on the profile of dermatophytosis in Tanjung Gusta Prison in Medan, was found from 90 people sampled for this case study, 23.3\% of cases occurred in the age group 41-45 years with the most dermatophytes species was Trichophyton rubrum [4].

In North Sumatra, data on the profile of dermatophytosis is still very minimal and difficult to find, especially in Sibolga which is an area with high risk factors for dermatophytosis. Sibolga has a fairly hot climate which makes it easy for people to sweat while on the move, in addition Sibolga people generally work in the field of fisheries with high humidity intensity which is very possible for mushrooms to grow and form colonization. Public awareness of Clean and Healthy Behavior 
(CHB) has not been fully met, it can be seen from the data obtained from the Sibolga City Health Office up to the end of 2016 as many as $49.6 \%$ of households that do PHBS [13]. According to the initial survey that the author conducted, in 2018 there were 308 outpatient visits from Sibolga City with dermatophytosis in Dr. Ferdinand Lumbantobing Sibolga. Based on these conditions the author wants to conduct research to see how the profile of dermatophytes that cause dermatophytosis that occurs in the skin and genital clinic Dr. Hospital. Ferdinand Lumbantobing Sibolga.

\section{Materials and Methods}

\subsection{Place and Year Work}

The present study was carried out for 5 months. Sampling was conducted from June to October 2019 at Dr. Ferdinand Lumbantobing Sibolga, while the sample management was carried out at the Microbiology Laboratory, Faculty of Medicine, University of North Sumatra.

\subsection{Ethics Statement}

The research was approved by The Health Research Ethical Committee of Faculty of Medicine Universitas Sumatera Utara. Written informed consent was obtained prior to the investigation.

\subsection{Subjects}

Data collection conducted in this study is by participatory observation method, the researcher is directly involved in the process of sampling and activities that will be carried out. The population in this study were all patients who came to the skin and genital clinic at the General Hospital Dr. Ferdinand Lumbantobing Sibolga. The sampling technique used in this study is total sampling, which is taking all samples conducted by referring to the inclusion and exclusion criteria set by the researcher. The sample in this study were all new patients diagnosed with dermatophytosis by skin and genital specialists who came to the Polyclinic Hospital Dr. Ferdinand Lumbantobing Sibolga with a minimum value of 75 patients obtained using the Slovin formula.

\section{$3 \quad$ Results and Discussions}

In this study, 75 specimens were collected in the form of skin scrapings, hair and nails with dermatophytosis sufferers. The sample is then divided into distribution based on several characteristics, one of which is gender. In this study, the frequency distribution of dermatophytosis based on sex can be seen in the following table: 


\begin{tabular}{lrr}
\hline & Table 4.1 Distribution of Dermatophytosis Frequency Based on Gender & \\
\hline Gender & Frequency & Percentage (\%) \\
\hline Man & 36 & 48 \\
Woman & 39 & 52 \\
\hline Total & $\mathbf{7 5}$ & $\mathbf{1 0 0}$ \\
\hline
\end{tabular}

Table 4.1 shows that there were 36 patients $(48 \%)$ who were male and 39 patients $(52 \%)$ were female. From this frequency distribution it is known that more women are diagnosed with dermatophytosis. This is in line with research conducted at the Aisiyah Islamic Hospital in Malang where there were also the same results, namely 12 samples (63.16\%) of female sex diagnosed with dermatophytosis. [14]

Table 4.2 Distribution of Dermatophytosis Frequency Based on Age

\begin{tabular}{lrr}
\hline Age & Frequency & Percentage (\%) \\
\hline$<12$ years & 12 & 16 \\
12 - 25 years & 17 & 22,7 \\
26 - 45 years & 19 & 25,3 \\
46 - 65 years & 23 & 30,7 \\
$>$ 65 years & 4 & 5,3 \\
\hline Total & $\mathbf{7 5}$ & $\mathbf{1 0 0}$
\end{tabular}

From table 4.2, it is known that the frequency of dermatophytosis sufferers based on age grouping is 23 people (30.7\%) in the $46-65$ years age group, followed by 19 people $(25.3 \%)$ in the $26-45$ years age group, 17 people $(22,7 \%)$ in the age group of $12-25$ years, 12 people (16\%) in the age group under 12 years, and 4 people (5.3\%) in the age group over 65 years. The most age group suffering from dermatophytosis is the age group 46-65 years, as many as 23 people, this result is the same as the research conducted at Prof. Dr. R. D. Kandou Manado for the period JanuaryDecember 2013, where the most age group of dermatophytosis cases was 46-64 years, namely 50 cases $(32.7 \%)[15]$.

Table 4.3 Distribution of Dermatophytosis Frequency Based on Occupation

\begin{tabular}{lrr}
\hline Occupation & Frequency & Percentage (\%) \\
\hline Government Employees & 5 & 6,7 \\
Enterpreneur & 16 & 21,3 \\
Fisherman & 5 & 6,7 \\
Driver & 3 & 4 \\
Pedicab driver & 2 & 2,7 \\
Household Assistant & 2 & 2,7 \\
Household & 18 & 24 \\
Pre-School & 2 & 2,7 \\
Student & 16 & 21,3 \\
College Student & 4 & 5,3 \\
Retired & 1 & 1,3 \\
Unemployee & 1 & 1,3 \\
\hline Total & $\mathbf{7 5}$ & $\mathbf{1 0 0}$ \\
\hline
\end{tabular}

Based on the results obtained from table 4.3, it is known that dermatophytosis is most often diagnosed among housewives, namely 18 people (24\%), followed by traders / entrepreneurs 16 people (21.3\%), 16 students (21,3\%), Civil Servants (PNS) 5 people (6.7\%), Fishermen 5 people (6.7\%), Students 4 people (5.3\%), Driver 3 people (4\%), Pedicab drivers 2 person $(2.7 \%)$, 
household assistant 2 people (2.7\%), 2 people (2.7\%) pre-school, 1 person (1.3\%) retired and 1 person $(1,3 \%)$ who don't work. This is in line with the research conducted by Sondakh et al at Prof. Dr. R. D Kandou Manado, where the most occupations found in dermatophytosis cases were IRT as many as 35 cases (22.9\%). Likewise with the research conducted by Wulan at Ciamis Hospital, West Java, where IRT was also found to be the most occupation in dermatophytosis cases, as many as 10 people from the total sample.[16]

$\mathrm{KOH}$ examination is one of the routines performed to help diagnose dermatophytosis. This examination uses a $10 \%$ potassium hydroxide $(\mathrm{KOH})$ solution for skin samples and $20 \% \mathrm{KOH}$ for nail samples. The distribution of the results from this examination is divided based on the positive or negative results on the $\mathrm{KOH}$ examination:

Table 4.4 Distribution of Dermatophytosis Frequency Based on KOH Examination

\begin{tabular}{lrr}
\hline KOH Examination & Frequency & Percentage (\%) \\
\hline KOH (+) & 35 & 46,7 \\
KOH (-) & 40 & 53,3 \\
\hline Total & $\mathbf{7 5}$ & $\mathbf{1 0 0}$ \\
\hline
\end{tabular}

Based on table 4.4, it can be seen that from 75 samples that were tested for $\mathrm{KOH}, 35$ (46.7\%) were positive results and $40(53.3 \%)$ were negative $\mathrm{KOH}$ results. This result is in line with the research conducted by Goffar at the Pirngadi Hospital Medan in 2015 where there were also more negative results on the $\mathrm{KOH}$ examination.[17]

Another examination needed to diagnose dermatophytosis is fungal culture. The media used for culture in this study was mycobiotic agar ${ }^{\circledR}$ (pronadisa), this medium is a good enough medium for culturing dermatophyte fungi. In this study, the distribution of culture results can be seen in the following table:

Table 4.5 Sample Distribution Based on Culture Results

\begin{tabular}{lcrr}
\hline Culture Results & Frekuensi & Persentase (\%) & \\
\hline Positive (+) & 41 & 54,67 \\
Negative (-) & 34 & 45,33 \\
\hline Total & $\mathbf{7 5}$ & $\mathbf{1 0 0}$ \\
\hline
\end{tabular}

From Table 4.5 it is known that of the 75 samples found 41 positive culture results and 34 negative culture results.

Table 4.6 Sample Distribution Based on Culture Results and KOH Examination

\begin{tabular}{lccr}
\hline \multirow{2}{*}{ KOH } & \multicolumn{2}{c}{ Culture_Results } & \multirow{2}{*}{ Total } \\
\cline { 2 - 4 } & Positive $(+)$ & Negative $(-)$ & $\mathbf{3 5}$ \\
\hline KOH $(+)$ & 20 & 15 & $\mathbf{4 0}$ \\
KOH $(-)$ & 21 & 19 & $\mathbf{7 5}$ \\
\hline Total & $\mathbf{4 1}$ & $\mathbf{3 4}$ & \\
\hline
\end{tabular}

Based on table 4.6, it is known that in this study there were 35 positive $\mathrm{KOH}$ results, 20

positive culture results and 15 negative culture results as well as 40 negative $\mathrm{KOH}$ results, 21 positive culture results and 19 negative culture results. From this table, it is known that there are differences in the results of the $\mathrm{KOH}$ examination and culture. This is the same as the results of 
research conducted by Jacob et al, namely, of the 187 samples studied, 137 samples were found to be negative on the $\mathrm{KOH}$ examination, while the culture found 109 positive cultures from all study samples. It is seen that more negative results are found on $\mathrm{KOH}$ examination and in culture, there are more positive results [18].

The prevalence of dermatophytosis in Indonesia is reported to be quite diverse. In this study, from the results of data collection conducted at the skin and genital clinic Dr. Ferdinand Lumbantobing Sibolga, obtained a total number of patients from June 2019 to October 2019 as many as 1128 people, then also obtained the total number of dermatophytosis patients as many as 260 people. The prevalence of dermatophytosis patients in the skin and genital clinic of Dr. Ferdinand Lumbantobing for the period June-October 2019 amounted to $23 \%$. These results are in line with research conducted at the Tanggerang Regional Hospital in 2011 which obtained a dermatophytosis prevalence of $27.89 \%$ [19].

Table 4.7 Dermatophytosis Frequency Distribution based on the location of the lesion

\begin{tabular}{lrr}
\hline Classification of Dermatophytosis & Frequency & Percentage (\%) \\
\hline Tinea Corposis & 32 & 42,7 \\
Tinea Capitis & 5 & 6,7 \\
Tinea Cruris & 23 & 30,7 \\
Tinea Pedis & 13 & 17,3 \\
Tinea Unguinum & 2 & 2,7 \\
\hline Total & $\mathbf{7 5}$ & $\mathbf{1 0 0}$ \\
\hline
\end{tabular}

Based on table 4.7 it is known that of the 75 samples there were 32 people (42.7\%) diagnosed with tinea corporis, 5 people were diagnosed with tinea capitis $(6.7 \%), 23$ people $(30.7 \%)$ were diagnosed with tinea cruris, 13 people $(17,3 \%)$ were diagnosed with tinea pedis and 2 people $(2,7)$ were diagnosed with tinea Unguinum. Based on the table, it is also known that the most dermatophytosis classification is tinea corporis, which is 32 cases, this result is in line with a study conducted in a hospital in India which explains that tinea corporis is also the most common classification, which is $78 \%$ [20].

Table 4.8 Sample Distribution Based on Species of Dermatophytes

\begin{tabular}{lrr}
\hline Dermatophytes & Frequency & Percentage (\%) \\
\hline Microsporum canis & 1 & 1,3 \\
Trichophyton rubrum & 28 & 37,3 \\
Trichophyton mentagrophytes & 12 & 16 \\
Negative Cultures & 34 & 45,3 \\
\hline Total & $\mathbf{7 5}$ & $\mathbf{1 0 0}$ \\
\hline
\end{tabular}

Based on table 4.8 it is known that there are 1 species of Microsporum canis, 28 Trichophyton rubrum, 12 Trichophyton mentagrophytes and 34 negative cultures. In this study, it was found that the dermatophyte that caused the most dermatophytosis was the genus Tricophyton, namely 40 isolates consisting of 28 isolates of Trichophyton rubrum and 12 isolates of Trichophyton mentagrophytes. Trichophyton rubrum is the largest species that causes dermatophytosis. These results are in line with research conducted at Tanjung Gusta Class I Lapas, Medan, where the most dermatophyte results were Trichophyton rubrum as many as 76 people (85.5\%) [4]. 
$\overline{\text { In this study, } 41 \text { positive dermatophyte cultures were obtained from } 75 \text { samples. The distribution }}$ of dermatophytes to the incidence of dermatophytosis in this study can be seen in the following table:

Table 4.9 Distribution of dermatophyte species that cause dermatophytosis

\begin{tabular}{lrrrrr}
\hline \multirow{2}{*}{ Dermatophytosis } & \multicolumn{2}{c}{ Species of Dermatophytes } & \multirow{2}{*}{ Total } \\
\cline { 2 - 5 } & M. canis & T. rubrum & T. mentagrophytes & \\
\hline Tinea corposis & 0 & 10 & 9 & $\mathbf{1 9}$ \\
Tinea capitis & 1 & 0 & 0 & $\mathbf{1}$ \\
Tinea cruris & 0 & 11 & 2 & $\mathbf{1 3}$ \\
Tinea pedis & 0 & 6 & 0 & $\mathbf{6}$ \\
Tinea unguinum & 0 & 1 & 1 & $\mathbf{2}$ \\
\hline Total & $\mathbf{1}$ & $\mathbf{2 8}$ & $\mathbf{1 2}$ & $\mathbf{4 1}$
\end{tabular}

Based on table 4.9, it can be seen that 10 samples of tinea corporis were caused by Trichophyton rubrum and 9 samples by Trichophyton mentagrophytes; in tinea capitis as much as 1 sample caused by Microsporum canis; in tinea cruris, 11 samples were caused by Trichophyton rubrum and 2 samples by Trichophyton mentagrophytes; In tinea pedis, 6 samples were caused by Trichophyton rubrum; in tinea Unguinum as much as 1 sample caused by Trichophyton rubrum and 1 other sample by Trichophyton mentagrophytes. These results indicate that in tinea corporis, the most causative dermatophyte is Trichophyton rubrum with 10 samples and in tinea cruris, the most causative dermatophyte is also Trichophyton rubrum as many as 11 samples. This is in line with research conducted by Wulan et al at Ciamis Hospital, West Java which showed similar results, namely Trichophyton rubrum is the most common dermatophyte that causes tinea corporis and cruris $(95.8 \%)$. [16]

\section{Conclusions}

Based on research that has been conducted at Dr. Ferdinand Lumbantobing Sibolga in June October 2019, there were 260 cases of dermatophytosis and 75 cases were taken to be studied, it was found that the prevalence of dermatophytosis was $23 \%$ with the most dermatophyte species being tinea corporis. For the distribution of the frequency of dermatophytosis itself, the majority occurs in women, for the highest age group at the age of 46-65 years and for work the majority occurs in housewives.

\section{Acknowledgement}

I would like to express my gratitude to Department of Microbiology Clinic, Universitas Sumatera Utara and TALENTA Universitas Sumatera Utara for providing the opportunity for us to conduct this experimental study. 
[1] Carrol, K.C., Butel, J.S., ... Mietzner, T., 2015. Jawetz Melnick \& Adelbergs Medical Microbiology 27th Edition, McGraw Hill Professional.

[2] Koksal, F., Er, E., Samasti, M., 2009. Causative agents of superficial mycoses in Istanbul, Turkey: Retrospective study. Mycopathologia 168, 117-123. doi:10.1007/s110460099210-z.

[3] Rosita, C., Kurniati, 2008. Etiopatogenesis Dermatofitosis ( Etiopathogenesis of Dermatophytoses ). Berkala Ilmu Kesehatan Kulit dan Kelamin 20, 243-250.

[4] Anra, Y., Putra, I.B. and Lubis, I.A., Profil dermatofitosis pada narapidana Lembaga Pemasyarakatan Kelas I Tanjung Gusta, Medan. Majalah Kedokteran Nusantara The Journal Of Medical School, 50(2), pp.90-94.

[5] Abbas KA, Mohammed AZ, Mahmoud SI. 2012. Superficial Fungal infections. Mustansiriya Medical Journal. 11:75-7. Available at https://www.iasj.net/iasj?func=fulltext\&aId=52145.

[6] Kusmarinah, B., 2009. Epidemiologic Trend of Superficial Mycosis in Indonesia, Department of Dermato-Venereology, Faculty of Medicine, University of Indonesia, Cipto Mangunkusumo Hospital, Jakarta, Disampaikan pada Kongres National IV \& Temu Ilmiah Perhimpunan Mikologi Kedokteran Manusia dan Hewan Indonesia (PMKI) Manado.

[7] Kanti, E.A.A., Rahmanisa, S., 2014. Tinea Corporis With Grade I Obesity In Women Domestic Workers Age 34 Years. Fakultas Kedokteran Universitas Lampung Medula.

[8] Nussipov, Y., Markabayeva, A., ... Lotti, T., 2017. Clinical and Epidemiological Features of Dermatophyte Infections in Almaty, Kazakhstan. Open Access Macedonian Journal of Medical Sciences 5, 409. doi:10.3889/oamjms.2017.124.

[9] Bitew, A., 2018. Dermatophytosis: Prevalence of Dermatophytes and Non-Dermatophyte Fungi from Patients Attending Arsho Advanced Medical Laboratory, Addis Ababa, Ethiopia. Dermatology Research and Practice 2018, 1-6. doi:10.1155/2018/8164757.

[10]Kardhani, A., Rachmi, E., Nurjanti, L, 2009. Pola distribusi penderita Dermatofitosis berdasarkan unur, jenis kelamin, dan tipe klinis di bagian/SMF Ilmi Kesehatan Kulit dan Kelamin FK Unmul/RSUDAWS Samarinda, Tugas akhir skripsi hal 50-56.

[11]Khusnul, Kurniawati, I., Hidana, R., 2018. Isolasi dan Identifikasi Jamur Dermatophyta Pada Sela- sela Jari Kaki Petugas Kebersihan di Tasikmalaya. Kesehatan Bakti Tunas Husada 18, 45-50.

[12]Cyndi E. E. J Sondakh, et al., 2016 Profil Dermatofitosis di Poliklinik Kulit dan Kelamin RSUP Prof. Dr. R. D. Kandou Manado Periode Januari - Desember 2013, Jurnal e-Clinic (eCl),Volume 4, Nomor 1, Januari-Juni 2016.

[13]Sibolga, D.K.K., 2017. Profil Kesehatan Kota Sibolga Tahun 2016. Dinas Kesehatan Kota Sibolga.

[14]Hidayatullah, T.A., Nuzula, A.F. and Puspita, R., 2019. Profil Dermatofitosis Superfisialis Periode Januari-Desember 2017 Di Rumah Sakit Islam Aisiyah Malang. Saintika Medika: Jurnal Ilmu Kesehatan dan Kedokteran Keluarga, 15(1), pp.25-32.

[15]Sondakh, C.E., Pandaleke, T.A. and Mawu, F.O., 2016. Profil dermatofitosis di Poliklinik Kulit dan Kelamin RSUP Prof. Dr. RD Kandou Manado periode Januari-Desember 2013. e-CliniC, 4(1).

[16]Yuwita, W. and Ramali, L.M., 2016. Karakteristik Tinea Kruris dan/atau Tinea Korporis di RSUD Ciamis Jawa Barat (Characteristic of Tinea Cruris and/or Tinea Corporis in Ciamis District Hospital, West Java.

[17]Saragih, G.D., Depary, A.A. and Hutabarat, G.F., 2015. Karakteristik Penderita Tinea Korporis Dengan Diagnosa Penunjang Koh 10\% Di Dr. Pirngadi Medan Tahun 2014. Jurnal Kedokteran Methodist, 8(2), pp.24-28.

[18]Levitt, J.O., Levitt, B.H., Akhavan, A. and Yanofsky, H., 2010. The sensitivity and specificity of potassium hydroxide smear and fungal culture relative to clinical 
assessment in the evaluation of tinea pedis: a pooled analysis. Dermatology research and practice, 2010.

[19]Oktavia, A., 2012. Prvalensi Dermatofitosis di Poliklinik Kulit dan Kelamin RSUD Tangerang Periode 1 Januari 2011 sampai dengan 31 Desember 2011.

[20]Lakshmanan, A., Ganeshkumar, P., Mohan, S.R., Hemamalini, M. and Madhavan, R., 2015. Epidemiological and clinical pattern of dermatomycoses in rural India. Indian journal of medical microbiology, 33(5), p.134. 